\title{
Decentralization: the key to accelerating access to distributed energy services in sub-Saharan Africa?
}

\author{
Collen Zalengera ${ }^{1} \cdot$ Long Seng To ${ }^{2} \cdot$ Richard Sieff $^{2} \cdot$ Alison Mohr $^{3} \cdot$ Aran Eales $^{4} \cdot$ Jon Cloke ${ }^{2} \cdot$ Hannah Buckland $^{4}$. \\ Ed Brown ${ }^{2} \cdot$ Richard Blanchard ${ }^{2} \cdot$ Simon Batchelor ${ }^{5}$
}

Published online: 5 May 2020

(C) The Author(s) 2020

\begin{abstract}
The decentralization of governance is increasingly considered crucial for delivering development and is being widely adopted in sub-Saharan countries. At the same time, distributed (decentralized) energy systems are increasingly recognized for their role in achieving universal access to energy and are being promoted in sub-Saharan countries. However, little attention has been paid by governments and energy practitioners to the dynamic interrelationships between national and local government and the role of governance decentralization in transitioning to distributed energy systems. This paper traces the complex relationships between accelerated delivery of distributed energy and decentralized local governance systems. The argument is grounded in an exploration of two different approaches to decentralized energy systems governance in Kenya and Malawi. For Kenya, analysis focuses on the energy sector since the adoption of the new decentralized constitution in 2010. In Malawi, it focuses on the involvement of the authors in piloting Local Authority Energy Officers in districts under the decentralization of Malawian energy policy. Our analysis shows that accelerating the speed and scale of implementation for distributed energy systems and enhancing their sustainability and socio-economic impacts is directly linked to the quality of local and national governance structures and their interrelationships. The paper extends existing work in energy and evidence literacy for policy actors by developing an analytical framework, to enable more effective local governance within energy access initiatives in the Global South.
\end{abstract}

Keywords Decentralization $\cdot$ Distributed energy $\cdot$ Governance $\cdot$ Photovoltaics $\cdot$ Kenya $\cdot$ Malawi

\section{Introduction}

Decentralization has been widely adopted in the Global South to further socio-economic development (Beard et al. 2008; Faguet 2014; Romeo 2012; Smoke 2015), particularly in sub-Saharan Africa (SSA) (Mohmand and Loureiro 2017). In the energy sector, distributed systems are increasingly recognized for their potential in enhancing universal energy access goals in developing economies (UN 2018), particularly

Long Seng To

1.to@lboro.ac.uk

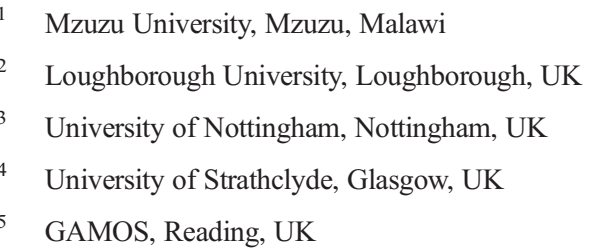

for remote areas. Despite the spread of administrative decentralization and energy systems decentralization, central governments across SSA face continuing challenges in providing universal energy access. To date little attention has been paid to the crucial role of local governance and the dynamics of national-local politics in transitioning to decentralized energy systems.

This paper therefore investigates the interplay between political governance and distributed energy systems based on evidence drawn from two case studies representing different approaches to local governance of distributed energy systems implementation. The second section outlines the methodology. The third section reviews the literature on decentralization to identify key factors for success to form an analytical framework for the feasibility of decentralized energy systems. The fourth section discusses empirical evidence from ongoing research on local energy governance in Kenya and from piloting district energy officers in Malawi. The fifth section compares the experiences of governance actors and stakeholders and the lessons learned in the two case studies. The last section 
concludes by reflecting on the implications of the findings for future research and evolution of decentralized energy governance.

\section{Methodology}

To understand the interplay between local governance and decentralized energy transitions, this paper first undertakes a review of the decentralization, energy studies and cognate literatures from which we educe a framework of seven factors for successful delivery of decentralized energy services. Empirical case study evidence from Kenya and Malawi is then presented and discussed with reference to the framework.

The literature review takes as its starting point from the UK Government funded Renewable Energy and Decentralisation (READ) project (see Brown et al. 2015), which found the energy and decentralization discourses had largely been discussed as separate entities resulting in a distinct lack of attention being paid to decentralized energy governance roles (Brown et al. 2015), a finding reinforced in a follow-on project on Kenyan decentralized energy governance (Sieff 2019). The two studies drew together literature on decentralized governance of other resources (e.g. water) and from other relevant discourses (e.g. capacity building in the development studies literature). This paper takes a similar approach, using insights from the decentralization, energy studies, geography, political economy and development studies discourses to identify key factors affecting the scope of decentralized energy governance to deliver distributed energy services in SSA.

Kenya and Malawi were selected as case studies as they are currently undergoing decentralization, which incorporates extensive energy sector reforms. Case studies are an effective means for exploring contextual details, the goal being to better understand complex social phenomena and real-life organizational and managerial processes (Yin 2009). The comparative experiences of the two countries are especially important as the stakeholder engagement and implementation processes have varied considerably, thereby offering alternative decentralized energy systems governance pathways. This paper does not seek to be an exhaustive study of experiences from across SSA, but seeks to illuminate key factors which could be useful for analysing decentralized energy governance and distributed energy in two countries at different stages of implementing changes in the energy sector as a result of decentralization.

Kenya was selected because a swiftly evolving political and energy context suggests that the country is well placed to establish effective decentralized energy governance. Kenyan political decentralization has extended rapidly since its introduction in 2013 and (unlike other SSA decentralization processes) has evidenced genuine reform. Cheeseman et al. (2016: 3) highlight that "decentralisation was neither killed at birth ... nor was it limited to a set of superficial measures with little significance". In terms of energy, the sector has been partly devolved, most notably, responsibility for county energy planning passed to the county level.

Kenya's energy infrastructure also seems facilitatory. Kenya has one of the world's largest per capita solar photovoltaic (PV) markets (Ondraczek 2013) and widespread mobile money to facilitate payment. Despite having the appearance at least of resources in place to contribute to successful energy governance and facilitate energy access, Kenya still has significant energy access issues, in part due to inadequate prioritization of distributed systems. These issues and inequalities challenge the assumption that decentralization automatically improves service delivery (Bennett 1990; Donahue 1997), providing instructive empirical lessons on the effectiveness of decentralized energy governance.

Malawi, in contrast to Kenya, appears to be adopting a more circumspect and prudent approach to decentralized energy reforms by designing the decentralized energy role prior to the devolved position being implemented (Buckland et al. 2017). Yet Malawi lacks the institutional capacity, resources and innovation of Kenya's energy sector, which the Malawi case study outlines in drawing on action research - the combination of empirical research with the practice of social intervention to produce social change (Lewin 1946) - that involved the piloting of district energy officers (DEOs).

\section{Decentralization and its relevance to the energy sector}

Decentralization refers to "the transfer of authority, powers, resources, and responsibilities from central to lowerlevel actors" (Wunsch 2014: 3), "a kind of governance reform, a mechanism to bring citizens, local groups and organizations into the policy and decision-making process" (Berkes 2010: 491). In the 1980s, decentralization was promoted by development agencies as a way to improve governance and service delivery by circumnavigating the perceived corruption, rent seeking and ethnic patronage of the centralized state (Cheeseman et al. 2016). By the 2000 s, such reforms had become a "cure-all prescription" (Cheeseman et al. 2016: 3); a means to variously "protect minorities, diffuse conflict, boost local development, and bring politics 'within the people's reach"' (D'Arcy and Cornell 2016: 246).

In SSA, centralized governance failings have been viewed as the major factor underlying the inability to 
deliver equitable energy services. The former United Nations (UN) Secretary-General, Kofi Annan stressed that "Governance of power utilities is at the heart of Africa's energy crisis. Governments often view utilities primarily as sites of political patronage and vehicles for corruption, providing affordable energy can be a distant secondary concern" (Africa Progress Panel 2015: 23). Grid electricity transmission and distribution tend to be powerful monopolies in the Global South and, given the tendency for rent seeking within such monopolies (Bigsten and Moene 1996), central governments are reluctant to decentralize the sector.

Despite these failings of centralized governance there has been insufficient attention paid to alternative decentralized energy governance systems (Brown et al. 2015), in contrast to the impact of decentralization on the governance of other sectors in the Global South (e.g. water, agriculture and forestry - see Asthana 2003; Cabral 2011; Ribot 1999) and on energy in the Global North (e.g. Cowell 2017). The few detailed explorations of this relationship suggest that decentralized governance has significant potential benefits for the energy sector. One such study was the UK Government-funded Renewable Energy and Decentralization (READ) project which explored the cases of Kenya and Rwanda. Batchelor and Smith (2014a) and Brown et al. (2015) highlight key potential benefits of decentralization for enhanced energy access: greater democratization, improved efficiency, improved access for all, improved security/resilience and greater affordability.

Decentralization has particular relevance to energy due to "the challenges that the highly complex nature of energy infrastructures pose for effective governance" (Brown et al. 2015: 9). Goldthau (2014: 134) elaborates on this energy sector complexity, stressing the particular challenges of infrastructure solutions spanning multiple scales, problems concerning common pool resources and the interactions between the existing dominant "socioeconomic institutions, regulatory agencies, incumbent market actors and social norms". Decentralized energy governance solutions need to coexist alongside centralized control to address these challenges. Sovacool (2011: 3832) highlights that such polycentric approaches to governance - those that mix scales, mechanisms and actors - "can foster equity, inclusivity, information, accountability, organizational multiplicity, and adaptability that result in the resolution of climate and energy related problems". Goldthau (2014: 134) argues that "the governance of energy infrastructure needs to be polycentric. This allows for contextualization, experimentation and innovation, which can lead to sustainable infrastructure solutions and learning across scales".
Yet, within these polycentric approaches, a critical research gap remains concerning the role of decentralized energy governance in Global South contexts and under what circumstances multi-scale governance arrangements work. Using the differentiated case studies of Kenya and Malawi, this paper addresses this gap by exploring the potential of decentralization energy governance to facilitate distributed solar PV initiatives.

\section{Distributed energy in sub-Saharan Africa}

The importance of distributed energy systems to addressing SSA energy access issues is evident from the ongoing deficiencies concerning centralized energy systems (here defined as large-scale generation facilities which deliver energy via a grid network and are often sited far from the point of use). Issues with centralized systems in SSA were outlined frankly by the former United Nations (UN) Secretary-General, Kofi Annan:

Africa's highly centralised energy systems often benefit the rich and bypass the poor and are underpowered, inefficient and unequal. Energy-sector bottlenecks and power shortages cost the region 2-4 per cent of GDP annually, undermining sustainable economic growth, jobs and investment. They also reinforce poverty, especially for women and people in rural areas. Africa's poorest people are paying among the world's highest prices for energy (Africa Progress Panel 2015: 8).

Annan's critique stresses the acute need for alternatives to centralized energy systems and their centralized governance in order to meet the commitment of the "Sustainable Energy for All" (SE4All) and Sustainable Development Goal 7 to ensure "access to affordable, reliable, sustainable and modern energy for all" (UN 2015).

Distributed energy systems hold considerable potential to address the problems centralized systems pose. They offer scope for relieving the loading of centralized grid systems, for increasing the proportion of sustainable clean energy production and for enhancing the reliability of supply in communities that are "under the grid" but unreliably supplied, as well as communities that are off-grid. This can be a particularly valuable aspect in SSA, where losses in the transmission and distribution network are double the world average due to poor maintenance (IEA 2014). The high cost of power relative to income has resulted in household electricity consumption rates in many countries in SSA being among the lowest in the world (IEA 2019). The IEA (2019) highlights the business case for distributed energy systems in SSA, noting that they are the least cost option for $55 \%$ of the population (30\% via 
mini-grids $/ 25 \%$ through stand-alone systems) obtaining access by 2030 . This clear business case for distributed energy systems challenges the status quo of prioritizing grid electricity by central governments in SSA.

Distributed energy systems take many forms with different technologies, but solar PV services (any of the services that can be provided utilizing the electricity obtained from a PV panel) play a major role in meeting the energy challenge in SSA. The technology has particular relevance due to the high solar irradiance in the region, the increasing affordability and the modularity of the technology, which enables distributed solar PV services to operate at different scales with different generating capacities to address a wide range of needs (see Table 1).

The modularity of solar PV enables the delivery of smaller community-scale energy initiatives, whose more localized scale would appear to be better facilitated by more locally attuned decentralized governance. The following section discusses these potential benefits as well as the challenges for implementing distributed solar PV services within evolving decentralized governance structures.

Decentralized energy governance seems well placed to play a leading role in distributed energy, principally clean cooking and small-scale off-grid initiatives. Such technologies are largely free from the natural monopolies inherent in grid electricity (i.e. one state-owned grid network). Cost reductions (particularly in solar PV) suggest the economics driving the traditional centralized approach might no longer apply, thus enabling greater use of distributed energy, whose more localized level of operations appears to align with the remit of decentralized governance (Levin and Thomas 2016).

\section{Distributed solar PV energy services and decentralization}

Current provision of solar PV services across SSA is based on complex interactions between a wide variety of stakeholders: government (national and local), local energy officers, NGOs, private operators, local finance and supply chains, installers and end-users (individual, institutional and community). The multi-scalar technical, legislative, capacity and social factors affecting uptake of solar PV services (see below) are strongly related to the context of broader national political regulatory frameworks and economic models, which reflect the centralized ethos of much government thinking on energy. Given the continued dominance of grid-based approaches to electricity generation and distribution and supply, energy governance structures remain highly centralized in most countries, although some states have attempted to devolve government responsibility to lower levels with varying degrees of success (Batchelor and Smith 2014a).

The growth of interest in off-grid solutions to meet energy access objectives and in particular the search for effective models for the development of mini-grids brings energy access firmly into the arena of community governance, with impacts on the quality of provision of other services. Political governance of services could be far more decentralized than it currently is, and in many cases, access delivery could be a function of local government. Brown et al. (2015) give several examples of where such initiatives have been developed, noting local level public officials - given appropriate training and resourcing-can be a pivotal stakeholder.

Drawing on such findings from a range of literatures, but principally the decentralization and energy studies discourses, the key technical, legislative, capacity and social factors affecting the potential of decentralized energy governance to deliver distributed energy services in SSA are outlined below as seven framework factors (FF). These seven interrelated factors serve as a framework for the subsequent analyses of the Kenyan and Malawian experiences of decentralized energy governance in the "Country case studies" section.

\section{Factors for successful decentralized energy governance and delivery of distributed energy services in sub-Saharan Africa}

\section{Decision-making power, autonomy and accountability (FF1)}

Although decentralization in SSA has been widespread, it has not been deep (Cabral 2011); central governments often continue to dominate partly due to notable discrepancies emerging between decentralization legislation and realities shaped by what Erk (2014: 536) terms "long-term

Table 1 Comparison of distributed solar PV systems for local energy provision. Power values are based on the experience of the authors as defined ranges are not exact

\begin{tabular}{|c|c|c|c|c|c|}
\hline Scale of solar PV service & Pico solar & Solar home systems (SHS) & Solar water pumps & Nano-grids & Micro-grids \\
\hline Typical power range & $1-10 \mathrm{~W}$ & $10-200 \mathrm{~W}$ & $50 \mathrm{~W}-5 \mathrm{~kW}$ & $1-3 \mathrm{~kW}$ & $3 \mathrm{~kW}-100 \mathrm{~s} \mathrm{~kW}$ \\
\hline $\begin{array}{l}\text { Example services } \\
\text { provided }\end{array}$ & Solar lantern & $\begin{array}{l}\text { LED lamps } \\
\text { Phone charging } \\
\text { Fan } \\
\text { Radio }\end{array}$ & $\begin{array}{l}\text { Drinking water } \\
\text { and/or irrigation }\end{array}$ & $\begin{array}{l}\text { Economic activity with light } \\
\text { power load requirements, } \\
\text { e.g. egg incubation, ICT or } \\
\text { community TV }\end{array}$ & $\begin{array}{l}\text { Greater levels of economic } \\
\text { activity with higher } \\
\text { loads, e.g. welding, } \\
\text { machining, milling }\end{array}$ \\
\hline
\end{tabular}


structural uncodified factors-be it societal, economic, geographic, demographic". ${ }^{1}$ As such, sub-Saharan decentralization has often most closely resembled deconcentration or delegation - weaker forms of decentralizationrather than the fuller, political devolution (see Table 2). These weak forms have often been used by elites to consolidate central power by creating positions which either divide opposition power bases or are filled by officers loyal to central government (Crook 2003). Examples of these weaker forms are common to the energy sector and illustrate how the concept of decentralization can be mobilized by different stakeholders and applied to energy policy and energy governance to serve different agendas. These limitations reinforce the need for case study analyses to help verify whether decentralization reforms have led to genuine change in the energy sector.

\section{Understanding potential decentralized energy governance roles (FF2)}

The READ project identified a range of different roles that innovative local authorities have played in successful forms of local energy governance (Brown et al. 2015). These include situations where regional and local authorities have played a major role in the development of national grid and off-grid electrification initiatives in South Africa, Brazil, Nepal, India and Chile. Some individual municipalities and regional authorities have run their own energy programmes, such as specific waste-toenergy initiatives with private sector partners and funding pilot community energy programmes.

Further roles for decentralized governance in PV services seem likely to emerge. Recent findings from the Modern Energy Cooking Services (MECS) programme indicate the off-grid electric cooking sector is rapidly evolving in SSA and likely to become cost competitive with conventional fuels in the next 5 years (Batchelor et al. 2018). The roll out of PV cooking needs to consider socio-cultural cooking practicessuggesting that localized knowledge of decentralized governance is likely to be key.

However, despite this wide array of potential decentralized energy governance roles, capacity will be key to whether these roles are appreciated, understood and realized. In addition, clear lines of division of responsibility between decentralized energy services responsibilities and centralized services would also be needed between national and local government. The READ project noted decentralized energy governance initiatives in SSA are more effective where devolved roles have been clearly demarcated.

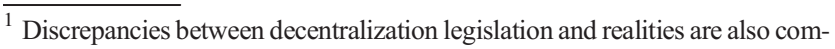
mon outside of SSA in both Global South and North contexts.
}

Table 2 Definitions of decentralization forms and their relevance to the energy sector (adapted from Gregersen et al. 2004; Cabral 2011)

Decentralization is commonly understood to incorporate three forms depending on the extent to which powers are distributed and the nature of accountability (Rondinelli et al. 1983).

Deconcentration

- Type of reorganization: involves the transfer of administrative responsibilities/functions to subordinate units of government, often on a geographical basis.

- Where decision-making power lies: at the centre.

- Energy sector example: a state energy monopoly establishes local offices to manage local administrative issues but not to devise independent, locally sensitive policies

Delegation

- Type of reorganization: consists of the transfer of responsibilities for public functions/services to semi-autonomous public entities (also referred to as parastatals).

- Where decision-making power lies: mostly at the centre, with the semi-autonomous entities implementing programmes for and accountable to central government but not wholly controlled by it.

- Energy sector example: a vertically integrated state-run energy entity is divided into separate semi-autonomous organizations, each responsible for a separate function of the sector: e.g. regulation, generation, distribution, retail

Devolution

- Type of reorganization: transfer of governance powers and responsibilities to sub-national levels, often via an electoral process which leaves sub-national authorities directly accountable to local people.

- Where decision-making power lies: transferred to the sub-national level and largely outside the direct control of the central government.

- Energy sector example: the sub-national level assumes decision-making control over functions of the local energy sector. These might include planning the local electricity distribution network or providing and maintaining local street lighting

\section{Access to resources (FF3)}

Thus far, decentralization initiatives in SSA have been widespread but consisted mostly of administrative deconcentration processes, characterized by insufficient power and resources to match responsibilities (Conyers 2007). The READ project noted that decentralized energy governance initiatives in SSA are more effective when sufficient budgetary control is transferred. The READ project also highlighted, however, that even in circumstances with limited resources, a dedicated district energy role can play a major part in campaigning for positive changes at a national level (for example securing change within the regulation of the energy sector) as seen in other countries (Bahingana and Wa Gathui 2014).

\section{Effective coordination between levels of governance (FF4)}

Both Batchelor and Smith (2014a) and Brown et al. (2015) argue that these potential benefits are socio-culturally dependent and significantly affected by the way decentralization is 
Table 3 Potential blueprint for the development of effective local solar PV services governance in localities where capacity is lacking (Batchelor and Smith 2014a)

\begin{tabular}{|c|c|}
\hline Attribute & Characteristic (developed/prioritized in consultation with stakeholders) \\
\hline Knowledge & $\begin{array}{l}\text { - Energy flows, systems and sources both within their control and within their influence and } \\
\text { outside of their control and influence } \\
\text { - Sustainable and renewable energy } \\
\text { - Units of measure for energy use } \\
\text { - Impact of individual and societal decision on energy development and use } \\
\text { - Impact of energy on development and economy } \\
\text { - General trends and initiatives in decentralized energy } \\
\text { - Basic scientific facts related to energy }\end{array}$ \\
\hline Skills & $\begin{array}{l}\text { - Assess the credibility of information about energy } \\
\text { - Communicate about energy and energy use in meaningful ways, both to peer colleagues } \\
\text { and to wider citizens } \\
\text { - Make informed energy decisions based on an understanding of impacts and consequences } \\
\text { - Obtain, evaluate and utilize energy information from a variety of sources } \\
\text { - Identify energy aspects of personal and community concerns } \\
\text { - Reframe energy concerns where necessary to go beyond centralized delivery }\end{array}$ \\
\hline Attitudes & $\begin{array}{l}\text { - Awareness/concern with respect to global energy issues } \\
\text { - Positive attitudes and values for sustainable energy } \\
\text { - Assumption of personal responsibility for implementing sustainable energy } \\
\text { - Civic orientation (concern that knowledge benefits all and is distributed equally) }\end{array}$ \\
\hline Actor networks & $\begin{array}{l}\text { - Creation of space for dialogue within local authority } \\
\text { - Creation of linkages to actors outside authority concerned with energy (locally and } \\
\text { nationally) } \\
\text { - Creation of space for dialogue with citizens and citizen organizations } \\
\text { - Awareness of influences of "others" and discernment of vested interests }\end{array}$ \\
\hline $\begin{array}{l}\text { Changing } \\
\text { institutions }\end{array}$ & $\begin{array}{l}\text { - Awareness of resources available for "energy"-within their institution, locally and } \\
\text { nationally } \\
\text { - Willingness to reassess resource allocation for energy concerns } \\
\text { - Developing capacity within organizations to allow them to understand and respond to } \\
\text { energy issues } \\
\text { - Influencing strategy within own and other organizations to allow them to understand and } \\
\text { respond to energy issues } \\
\text { - Influencing strategy for citizens to allow them to understand and respond to energy issues }\end{array}$ \\
\hline Behaviour & $\begin{array}{l}\text { - Communicates information about energy issues not only as a personal concern but also as } \\
\text { a problem affecting the larger community } \\
\text { - Implements and evaluates effective policies and projects } \\
\text { - Encourages others to implement effective policies } \\
\text { - Shares information and learning }\end{array}$ \\
\hline
\end{tabular}

viewed and operated. The potential benefits depend on the presence of effective multi-level coordination and consultation, in terms of competences, commitment and resources. Other key coordination roles local authorities can play include ensuring that NGO and private sector energy initiatives connect effectively into local and regional development strategies and local programmes in water, education and health and providing information and training about energy issues among their local communities. The study identified that local authorities had a "demonstrator" role in promoting new technologies and approaches in service delivery advocated by the state,
NGO or private sector, such as the use of clean energy technologies in powering municipal buildings.

\section{Multi-scalar power relations and stakeholder interactions (FF5)}

Batchelor and Smith $(2014 a, b)$ suggest the quality of decentralization is partly dependent on the interrelationships between different actors operating at different scales, which in turn are shaped by underlying power dynamics. Investigating these interactions and power dynamics is crucial to 
ascertaining the effectiveness of decentralized energy governance roles. These concerns seem particularly pertinent to solar PV where political economy factors have been shown to be highly influential in undermining the sector (Newell and Phillips 2016).

Power relations are likely to differ significantly by locality with findings in the literature emphasizing that spatially contingent empirical approaches (as undertaken by this paper) are needed to uncover the on-the-ground relationships, agendas and interactions which shape the power relations underpinning forms of governance (Griffin 2012). Understanding these spatial variations is largely dependent on analysing the complex interactions between the wide variety of stakeholders operating in the distributed PV space. Griffin (2012, p. 209) notes that "power relations are not present in models, territories or networks: they are made and remade in relationships, exchanges and interactions".

\section{Facilitating local actor networks (FF6)}

A critical aspect is that new stakeholder arrangements in local energy governance need to be able to not only navigate these power dynamics but also engage communities and create stable actor networks (Batchelor and Smith 2014b). Recent contributions to the innovations systems literature have highlighted how the development of the Kenyan solar PV solar home systems (SHS) market was driven by a range of capacitybuilding initiatives undertaken by a diverse network of actors, which enabled the market to grow by reducing the risks that would have deterred private investment (Ockwell and Byrne 2017). Local actors are well positioned to facilitate the conditions noted by the innovation systems literature for the development of such technologies.

\section{Local capacity (FF7)}

Local authorities at least in principle are more closely associated with local communities than national government and thus have the potential to better understand the dynamics of local situations and local needs for PV energy services and where community awareness raising and/or training on PV services might be needed. For local governance to function well in this role, the requisite capacity is critical yet often lacking, particularly in terms of having some level of energy proficiency to understand and weigh the options.

The skill set required for a functional local energy officer, for example, goes well beyond a simple technical competency. Batchelor and Smith (2014a) explore this in detail and present a simple framework encompassing the basic range of skills. These include the social processes of incorporating solar PV services in everyday life. Table 3 presents a potential blueprint for the development of effective local solar PV services governance in localities where such capacity is lacking. Text in italic indicates a wider more powerful role for local governance actors, beyond just efficient delivery of energy services, to promote local interests.

Proficiency of local authority personnel needs to include an understanding of the limitations as well as the potential of solar PV services. It is also important that local governance structures are aware of innovations in solar PV services being developed, such as novel payment systems (Onyeji-Nwogu et al. 2017), energy efficient appliances (Park and Phadke 2017) and new emerging markets for solar PV-based electric cooking (eCook) being developed (Brown et al. 2017). Local governance can take steps to ensure that solar PV products on the market are of good quality (assured by relevant standards laboratories) and lastly can provide support, not just for the technical operation and maintenance of solar PV systems but in devising appropriate financial models.

\section{Country case studies}

Given the success factors outlined in the previous section, this section seeks to understand the spatio-temporal dimensions affecting decentralization and decentralized energy systems by focusing on two case studies, Kenya and Malawi, whose recent, differentiated decentralization processes offer rich and often contrasting insights into the potential of decentralized energy governance. Both case studies provide evidence about the quality of decentralized energy governance to support distributed solar PV energy services using the key factors outlined in the "Factors for successful decentralized energy governance and delivery of distributed energy services in sub-Saharan Africa" section as a guiding framework. The evidence emerging from the two countries builds on and develops arguments within the existing literature, focussing on the relationship between decentralization and energy access. The contrasting contexts of the two countries provide scope for a better understanding of which of the framework factors (FF) are most critical in terms of decentralized energy governance and distributed energy services, as well as under which circumstances they are most effective.

\section{Kenya}

Kenya is a lower middle-income country with a population of $51,393,010$ ( $73 \%$ rural) and a mixed economy comprised of three main sectors: services (43\%), industry (16\%) and agriculture (34\%) (World Bank 2019a). Access to electricity rose from $32 \%$ of households in 2013 to $75 \%$ by the end of 2018 , mainly as a result of grid extension initiatives driven by the forthcoming presidential elections (IEA 2019; KPLC 2018). However, electrification rates are far lower in rural areas, where in 2017 access stood at $58 \%$ compared to $81 \%$ in urban areas (IEA 2019). In addition, the government data does not 
Table 4 Kenya electricity demand and capacity (EACREE 2019; Kamau 2019)

\begin{tabular}{llllll}
\hline Year & $\begin{array}{l}\text { Peak demand } \\
\text { (MW) }\end{array}$ & $\begin{array}{l}\text { Reserve margin } \\
\text { (MW) }\end{array}$ & $\begin{array}{l}\text { Total capacity } \\
\text { required (MW) }\end{array}$ & $\begin{array}{l}\text { Available capacity } \\
\text { (MW) }\end{array}$ & $\begin{array}{l}\text { Excess capacity } \\
\text { (MW) }\end{array}$ \\
\hline 2018 & 1832 & 300 & 2132 & 2712 & 580 \\
\hline
\end{tabular}

elaborate on access disparities between rich and poor, and quality of supply, with blackouts frequent particularly in rural areas (ESI-Africa 2016).

Crucially, the government figures represent grid coverage rather than actual electricity use, with many Kenyans unable to access the available electricity due to affordability (Lee et al. 2016). Nonetheless, inability or unwillingness to pay for grid electricity is the key underlying reason for the large surplus of electricity capacity (see Table 4). Maintaining this unused capacity incurs costs, further impeding affordability and uptake - a vicious circle. Ongoing electricity infrastructure developments and the continual downward revision of projected demand scenarios (due to the very small amounts of electricity used by poorer/rural households, for instance) indicate this excess capacity is set to continue or even increase (see Table 5).

The Kenyan electricity sector has operated as a mixed state/ private sector entity since the 1990s. The previously highly centralized, state-run Kenya Power and Lighting Company (KPLC) was unbundled between 1996 and 2006 as part of conditional loans from the World Bank and IMF which sought to liberalize the electricity sector. The discrete functions of the electricity sector (e.g. generation, transmission, distribution, retail) were divided among newly formed "parastatals" (semi-autonomous public entities) while private sector participation was enabled, particularly for independent power producers (IPPs) to generate electricity.

At the time of the unbundling, energy roles at the district level (the sub-national level of governance in Kenya at the time) were not envisaged, later posing challenges for decentralized energy governance by depriving the successor county governments of sub-national energy capacity to inherit (FF7). Furthermore, the liberalizing reforms did little to alter the centralized governance of the Kenyan electricity sector. The terms and conditions of power purchase agreements (PPAs) for IPPs are determined by the Energy and Petroleum Regulatory Authority (EPRA) while KPLC remains the sole off-taker and retailer, and main distributor of

Table 5 Kenya projected and revised electricity demand (Batchelor et al. 2019; EACREE 2019; Obulutsa 2019)

\begin{tabular}{lcl}
\hline Year & Projected demand (MW) & Actual/revised demand (MW) \\
\hline 2020 & 5000 & 1832 \\
2030 & 10,000 & 7200 \\
\hline
\end{tabular}

grid electricity, thus ensuring a de facto national government monopoly (Fig. 1). These reforms thus clearly constitute a form of "delegation" (Table 2), with the parastatals and IPPs still responding and accountable to the centre (FF1).

\section{Kenya energy policy and decentralization}

The political economy of Kenya's energy context suggests that, despite the challenges outlined above, it is well placed to establish an effective decentralized energy regime which could facilitate distributed solar PV transitions. Decentralization in Kenya, central to the constitution adopted in 2010 and instituted after the 2013 general election, has been cited as one of "the most rapid and ambitious devolution processes going on in the world" (World Bank 2015). The newly created 47 county governments have been allocated political, fiscal and administrative powers over delivery of key services (e.g. healthcare), with executive powers held by governors and legislative powers by the members of county assemblies (MCAs) (D'Arcy and Cornell 2016).

The election from each county of one senator to the newly formed Senate and one women's representative to the National Assembly also provides counties with national level representation (Fig. 2), reforms reinforced by constitutional protections to governors and senators, specified devolved roles in the Constitution (a regional rarity) ${ }^{2}$ and the guarantee of at least $15 \%$ of national revenue to the counties. This means that "in practice the Kenyan system is closer to Nigerian federalism than the sort of limited decentralisation practiced in Malawi and Uganda" (Cheeseman et al. 2016: 15); the extensiveness of Kenyan decentralization means the process has been considered a strong or even "quasi-federal" form of devolution (Kangu 2015), likely to lead to genuine reform and thus offer scope for decentralized energy governance (FF1).

As part of the "Kenya Vision 2030" policy to achieve middle-income status by 2030 , energy is seen as "a key foundation and one of the infrastructural 'enablers' upon which the economic, social and political pillars of this long-term development strategy will be built" (KETRACO 2017). The Kenya Vision 2030 policy has set energy targets in line with those of the United Nations' SE4All strategy (SE4All 2017b) and universal access to electricity is to be achieved by 2022, 8 years ahead of the global SE4All target (World Bank 2018).

\footnotetext{
${ }^{2}$ The allocation of national and county government functions is found in the Fourth Schedule to the Constitution. Thirty-five functions are allocated to national government and 14 for county governments.
} 
Fig. 1 Institutional structure of the Kenyan electricity sector (adapted from KETRACO 2017). Kengen, Kenya Electricity Generating Company; GDC, Geothermal Development Company; KETRACO, Kenya Electricity Transmission Company. The Energy and Petroleum Regulatory Authority (EPRA) and the Rural Electrification and Renewable Energy Corporation (REREC) were established as successors to the Energy Regulatory Commission (ERC) and the Rural Electrification Authority (REA) respectively under the GoK 2019

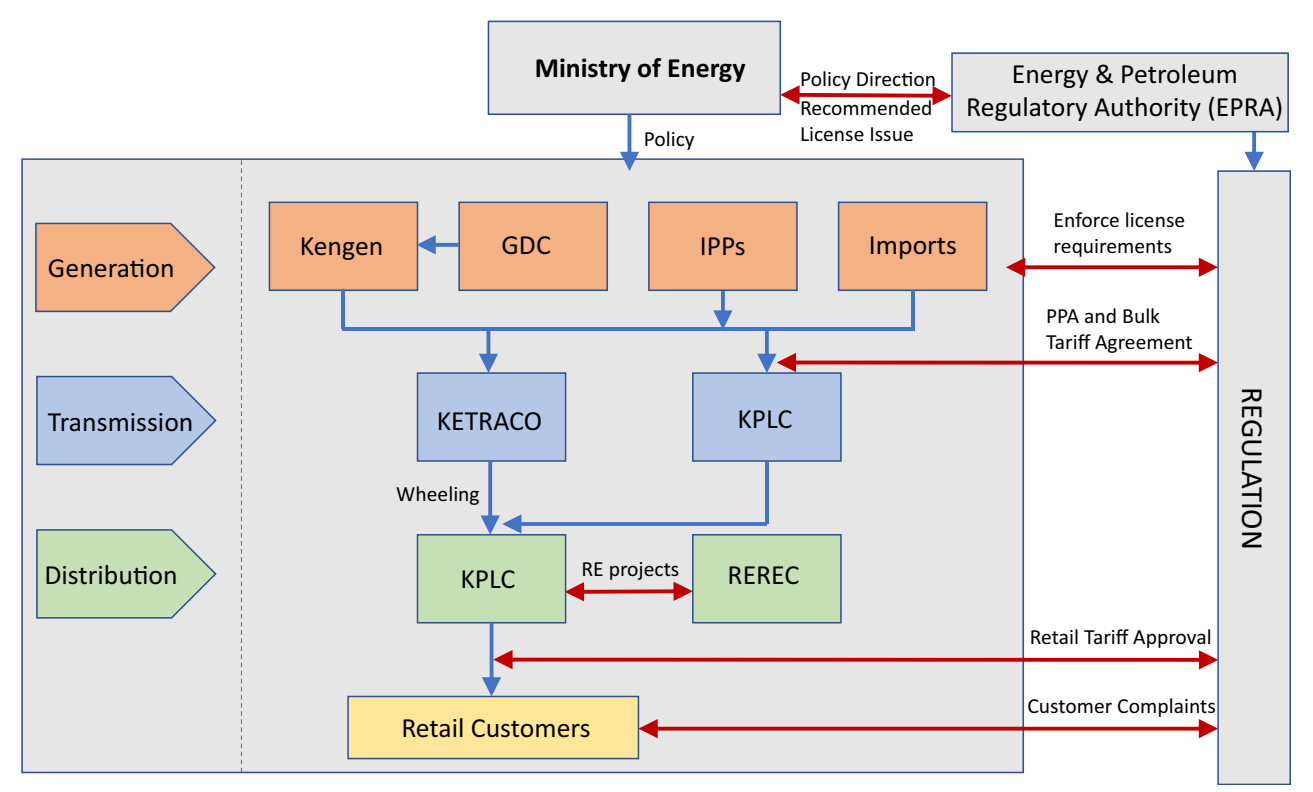

Nonetheless, until 2019, efforts to achieve Kenya's electrification targets were governed by The GoK 2006, introduced before decentralization and containing almost no guidance for devolved electricity roles. This was compounded by the structure of the new Constitution (GoK 2010), ${ }^{3}$ which provided only a broad overview of county energy roles, stipulating the main county function as "planning and development [of ] ... electricity and gas reticulation and energy regulation" but providing no specifics of what that planning should encompass (Table 6). The roles also appear to overlap national government functions, with county government responsible for "electricity and gas reticulation and energy regulation" (FF2).

In cases of overlap, the Constitution (article 186(2)) states jurisdiction is "concurrent" (i.e. shared), but the Constitution does not explicitly demarcate concurrent functions, which instead "must be determined through interpretation" as Kangu (2015: 193) explains. Where concurrent roles are identified, article 6(2) calls for negotiation, stating that "The governments at the national and county levels are distinct and interdependent and shall conduct their mutual relations on the basis of consultation and cooperation"- a clear nod to the stakeholder coordination identified in FF4 - where roles are clearly not sufficiently demarcated or understood (FF2); however, it remains doubtful how feasible that coordination is.

The Constitution's lack of specificity concerning energy roles contrasts markedly with the breakdown provided for other sectors such as agriculture and health, suggesting the devolution of energy was not clearly envisaged. Indeed, there was tacit understanding at the time of the Constitution's

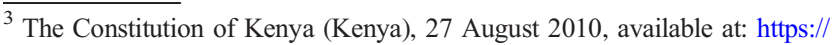
www.refworld.org/docid/4c8508822.html (accessed 19 March 2020)
}

unveiling of the need to clarify energy roles, with an energy bill to replace the GoK 2006 being considered during President Kibaki's second administration (2008-2013). The first draft (the Energy Bill 2015) was not released until 2015 and not promulgated until March 2019 when the GoK 2019 was introduced.

The Energy Bill 2015 and GoK 2019 provide a detailed breakdown of national and county energy roles, ${ }^{4}$ revealing that the energy sector in Kenya has only been partly devolved. Most key grid electricity functions are still held at national level, including energy policy, generation and high voltage transmission (FF1). Functions which have been devolved appear to provide some opportunities to establish a platform for effective local energy governance and better understanding of local needs (principally energy planning) which requires county governments to prepare county energy plans that feed into national energy planning (FF7). These documents recognize the role of distributed energy and are expected to form the basis for county governments to plan and implement solar PV initiatives.

To date, there is little or no provision for autonomous, streamlined county level decision-making as all regulatory oversight in the electricity sector is held by the national government $(\mathrm{FF} 1,5)$. While this is understandable with grid electricity for reasons of national coordination, the need for national government permissions for distributed energy initiatives (which are not for own use-Day et al. 2019) makes less sense. These systems could run autonomously or in parallel to

\footnotetext{
${ }^{4}$ The list of national and county functions is the same in both the Energy Bill 2015 and GoK 2019.
} 
Fig. 2 Structure of governance under the new Kenyan Constitution (adapted from Express Communications Ltd. 2015)

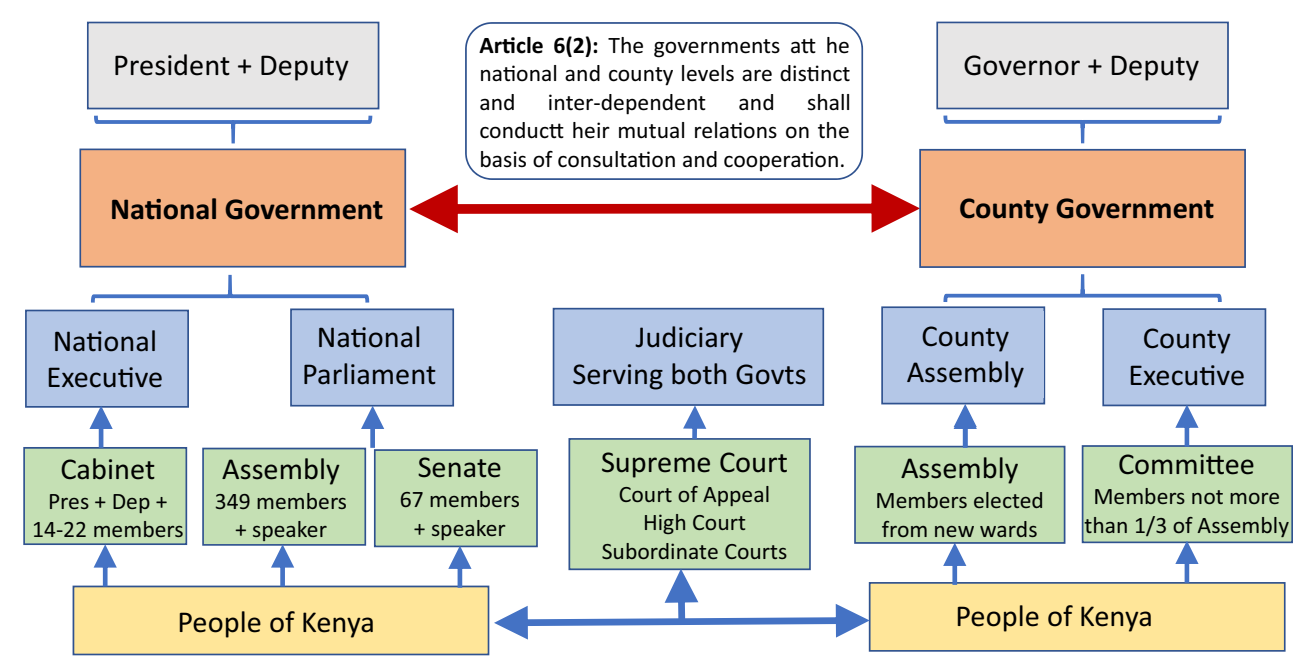

the grid and the stringent regulatory requirements are likely to disincentivize county interventions.

In addition, several of the energy functions in the GoK 2019 are concurrent and lack clear demarcation of where national government responsibility ends and that of the county starts, impeding coordination (FF4). This has the potential to lead to ambiguity over responsibilities and possibly erroneous shifting or assuming of roles (FF2), particularly in the case of the concurrent function of land rights (for energy projects), an emotive issue which could create intergovernmental tension (FF5). County uncertainties over roles have been exacerbated by the continued predominance of the electricity parastatals since devolution, which have only undergone limited internal restructurings to accommodate the decentralization process.

Meanwhile, KPLC has established offices in all 47 counties to aid the management of county administrative issues, a reform the Rural Electrification and Renewable Energy Corporation (REREC) is also in the course of implementing. While this redistribution of personnel has aided accountability by bringing those responsible for service provision closer to the people they serve, the restructuring constitutes a form of deconcentration as sub-national offices have little to no political or financial autonomy from their Nairobi head offices (FF1). The other four parastatals (EPRA, GDC, KenGen and KETRACO), whose activities operate at a more national scale and are less customer facing, have remained centralized, operating from head offices in Nairobi.
The limited restructuring of the electricity sector and lack of clear provision for county electricity roles seems to imply that deconcentration is what the national government would prefer, rather than autonomous, political and fiscal decentralization that might lead to resources and revenues being drawn from the centre. To date, resources continue to be consolidated in national government grid interests, potentially at the expense of bottom-up distributed electricity initiatives where national government would have less control (FF3). Given that energy is one of the top three most lucrative ministries (Wafula 2017) and alleged to be subject to elite capture (Musau 2018), the central government preference for deconcentration seems to reflect how energy, more than other resource areas, is seen as too politically and financially important to fully devolve. A reluctance to cede power is characteristic of decentralization processes in both the Global South and North (FF5) (Rodríguez-Pose and Gill 2003).

\section{Distributed energy systems in Kenya}

Current distributed energy provision consists of 21 parastatal run mini-grids generating $67.6 \mathrm{MW}$ (2.5\% of total installed capacity) (Table 7) and at least 40 smaller private or community run systems totalling around $500 \mathrm{~kW}$ (Day et al. 2019). In addition, there are 700,000 households with stand-alone SHS (Alupo 2018) - the world's second largest SHS market after China (Ondraczek 2013). There is a critical need for further
Table 6 Allocation of energy functions in the Constitution of Kenya (GoK 2010)

\begin{tabular}{ll}
\hline National government function & County government function \\
\hline $\begin{array}{l}\text { Energy policy including electricity and gas } \\
\text { reticulation and energy regulation (31) }\end{array}$ & $\begin{array}{c}\text { County planning and development (8) including (e) electric- } \\
\text { ity and gas reticulation and energy regulation } \\
\text { Street lighting (5b) }\end{array}$ \\
\hline
\end{tabular}

Function number as listed in the Constitution provided in brackets 
distributed energy solutions - grid extensions alone will not reach the entire population of Kenya due to the dispersed nature of Kenya's large rural population and low energy demand, which leaves grid extension initiatives to those areas logistically and economically unfeasible. An extensive World Bank funded report found that 1.1 million households (10.2\% of the national total) - mostly in the 14 historically marginalized arid and semi-arid (ASAL) counties - are beyond the grid's viable reach and require distributed energy solutions (Alupo 2018).

As the minimum value of the solar resource in Kenya stands at a monthly average of $4.7 \mathrm{kWh} / \mathrm{m}^{2} /$ day and is even higher in the ASAL counties, solar PV-distributed systems offer particularly significant opportunities to address this electricity access issue (WorldClim 2017). The Kenyan National Electrification Strategy envisages 35,000 of the households beyond the grid's reach will be connected via mini-grids, the other 1,070,000 through SHS (Alupo 2018). This represents an opportunity particularly for counties whose localized scale is favourable for facilitating the conditions the innovation systems literature cite as crucial: namely, counties well-placed to build networks of diverse local stakeholders, conduct market research, raise awareness and fund experimental initiatives to foster community scale distributed solar PV (Ockwell and Byrne 2016).

\section{A defining role for decentralized energy governance of distributed solar PV services in Kenya?}

Despite the potential for county government to play a key role in distributed energy, county interventions have thus far been limited. The delay over the Energy Bill 2015 for the first 6 years of devolved government created ongoing legislative uncertainty over county roles; many counties were understandably unwilling to devote time and limited resources to roles which might not exist. This is perhaps most vividly illustrated by the fact that nearly half the 47 county administrations did not have an energy department within their permitted 10 ministries during their first terms - a clear impediment to developing local capacity (FF7).

The reluctance to innovate has also been exacerbated by national government prioritization of resources towards grid extension initiatives (Table 8) (FF3). State support for solar PV services has been lacking; feed-in tariffs have been set too low by the government to attract investment, largely reflecting the interests of state institutions (Newell and Phillips 2016). This has led to investment focussing on the national level and policy favouring centralized electricity technologies, such as geothermal, rather than distributed alternatives (Ockwell and Byrne 2017).

The pursuit of centralized electricity limits the scope for policy which best aligns with Kenya's own development priorities (Newell and Phillips 2016) (FF5) and appears to have
Table 7 Kenya distributed electricity (off-grid) capacity (IRENA 2019; ESMAP 2016)

\begin{tabular}{lc}
\hline Energy source & Capacity (MW) \\
\hline Solar & 36.8 \\
Hydro & 6.4 \\
Other RE & 0.7 \\
Diesel & 23.7 \\
Total & 67.6 \\
\hline
\end{tabular}

contributed to energy being under-resourced by counties (FF3). In particular, the lack of county energy departments seems to have been partly due to a misunderstanding of roles within some county governments, who see energy as gridbased electricity centrally generated from national government (FF2, 3). This perception of energy as still essentially a national function is undoubtedly a perception encouraged in socio-political systems in which the ability to act as gatekeeper to electricity and thereby modernity is a valuable political resource (FF5).

Cost is another key barrier to county government interventions in larger distributed solar PV mini-grids, particularly as communities living outside the current and predicted reach of the grid tend to be more dispersed, poorer, low energy consumers (Ndii 2019). This creates a lengthy payback period for the large upfront capital expenditure required, necessitating subsidies likely beyond the reach of county governments and/or private sector investment (FF3). Indeed, despite the fiscal provisions of the Constitution, frequent criticism tabled by the counties ${ }^{5}$ is that funding is not sufficient for the responsibilities devolved (Cheeseman et al. 2016).

The primary initiative to expand mini-grids is a joint national government/donor venture, the World Bank financed "Kenya Off-Grid Solar Access Project" (KOSAP), which aims to provide off-grid electricity to the 14 ASAL counties (Kenya Power, 2017). However, this initiative seems likely to further disincentivize decentralized governance in the sector, as acknowledged by the World Bank:

Programs as KOSAP are seen as hindering innovation and additional revenue streams, putting control back with KPLC that already enjoys a quasi-monopoly. Some suggest that $\mathrm{MoEP}^{6}$ and ERC consider leaving existing agreements unchanged; and keep the market open for models that work outside the KOSAP program, which comes with limited funding (ESMAP 2017, p. 41).

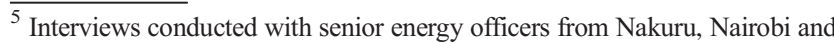
Turkana county governments in 2017.

${ }^{6} \mathrm{MoEP}$ (Ministry of Energy and Petroleum) was separated into the Ministry of Energy and the Ministry of Petroleum and Mining in 2018.
} 
Table 8 Largest national government led initiatives in each energy sub-sector by US\$ of investment (Kenya Power 2017; Anyanzwa 2018; Kipsang 2018; European Union (EU) 2019; World Bank 2019b; CIO 2019)

\begin{tabular}{llll}
\hline Energy sub-sector & Projects & Financed by & Investment \\
\hline Grid electricity & LMCP (phases I and II) & World Bank (US\$450), AfDB (US\$270), & Government of Kenya (US\$30 M), EU (33 M) \\
& DLP & Government of Kenya & US\$267 M \\
Off-grid electricity & Kenya Off-Grid Solar Access & World Bank & US\$150 M \\
& Project (KOSAP) & & \\
\hline
\end{tabular}

This recognition that major national government distributed electricity initiatives such as KOSAP can potentially limit innovation and create conditions likely to be detrimental to decentralized governance interventions and the distributed electricity sector more broadly (Byrne et al. 2014) (FF4, 6). Other donor interventions such as the DfID Green Mini Grid Facility Kenya initiative (GMG 2018) and GIZ Pro Solar project adopted similar approaches (GIZ 2018).

The predominance of national government over off-grid systems may also be detracting from the more feasible role counties could play in smaller community level off-grid systems and SHS, which have lower costs and payback periods. County led initiatives in this field have been limited, with collaborations on initiatives such as the donor driven SONG project in Nakuru an isolated example of what such interventions could achieve (Blanchard et al. 2017). A far more prominent energy feature of the first term CIPDs have been streetlight programmes, some solar PV, which are highly visible and therefore have political prestige. While it appears populist (rather than decision-making in the interests of overall development) street lighting has been prioritized over other energy access initiatives, being one of the few clearly demarked county specific functions (FF7).

County interventions to facilitate SHS initiatives have also been limited due to a perception that the SHS market is already dominated by well-established private sector players, such as M-Kopa and D-light. The widespread use of mobile money in Kenya to facilitate payment has likely further advanced the dominant perception of SHS as a market driven phenomenon (Van der Plas and Hankins 1998; Jacobson 2007). More recent analyses however suggest that development of the PV market was heavily dependent on donor funding, which helped create demand, build networks and absorb risks that the private sector alone could not shoulder (Ockwell and Byrne 2017) (FF2). This suggests that lack of county interventions in SHS constitute missed opportunities, through coordination activities and (potentially) subsidizing local stakeholders and capacity-building activities (FF4, 6). The limited appreciation by county governments of the roles they could play in distributed solar PV highlights the need for critical county capacity issues to be addressed, if the benefits of multi-stakeholder decentralized governance are to be realized (FF7).

Various actors (transnational, national and local) have engaged in capacity building with county governments but these interventions have been spatially uneven: some counties have received far more assistance than others (FF5). For instance, GIZ has supported the county governments of Marsabit, Turkana and Narok to develop their county energy plans, resulting in a greater emphasis on distributed solar PV which partly reflects GIZ's own interests in developing the solar industry.

The Kenyan Association of Manufacturers has engaged in capacity building with the seven counties containing the largest urban centres, reflecting interests in business and commerce and leading to a more prominent focus on energy efficiency and creating an enabling environment for clean energy investment (KAM/CEEC 2017). These examples highlight the potential of counties which do not have features which align with external stakeholder interests to be left behind (FF7).

\section{Malawi}

Malawi is a low-income country predominantly comprised of a rural population and heavily reliant on agriculture. According to
Table 9 Malawi electricity demand and capacity projections (GoM 2017a, b)

\begin{tabular}{lrrrrr}
\hline Year & 2014 & 2018 & 2022 & 2026 & 2030 \\
\hline Peak demand forecast (MW) & 378 & 720 & 1300 & 1950 & 2550 \\
Reserve margin (MW) & 69 & 104 & 162 & 227 & 287 \\
Total capacity requirement (MW) & 447 & 824 & 1462 & 2177 & 2837 \\
ESCOM (utility) supply (MW) & 351 & 429 & 429 & 429 & 429 \\
Capacity supply shortfall (MW) & -96 & -395 & -1022 & -1748 & -2408 \\
\hline
\end{tabular}


the Sustainable Energy for All Global Tracking Framework (SE4ALL 2017a), access to electricity in Malawi in 2014 was $18 \%$ overall: $11.4 \%$ from grid, $6.6 \%$ from off-grid solar (National Statistics Office 2019), $46.1 \%$ in urban areas and only 4.7\% in rural areas (UN 2017). Therefore, about 14.4 million people in Malawi have no electricity, and those with grid access regularly experience blackouts and brownouts. Generally, electricity supply in Malawi does not meet the demand of the population and the deficit is expected to steadily increase to 2408 MW by 2030, as shown in Table 9 .

Until 2017, the Electricity Supply Corporation of Malawi (ESCOM) was the sole centralized electricity supply service provider, responsible for all generation, transmission and distribution of electricity. In January 2017, ESCOM was unbundled to form the Energy Generation Company (EGENCO), responsible for electricity generation, with ESCOM now responsible for transmission and distribution (GoM 2018). As part of the restructuring, independent power producers (IPP) can now operate in Malawi and private service providers can also participate in providing off-grid services. The restructuring has led to some developments that have increased the installed capacity to $501.7 \mathrm{MW}$ (422.9 MW by EGENCO comprising 371.2 hydro and 51.7 generators; $78 \mathrm{MW}$ by Aggreko-diesel fired and $0.83 \mathrm{MW}$ by a grid-connected solar managed by ADL at the Kamuzu International Airport). The Malawi Rural Electrification Programme (MAREP) fund has been used to extend the national grid to 435 trading centres by 2015 (GoM 2015) - an example of delegation (FF1). The effect has been a focus on grid extension, with minimal government efforts on off-grid solutions until recently, stymying overall access to electricity in the country.

\section{Malawi energy policy and decentralization}

The Malawi Growth and Development Strategy III (MGDS III) (GoM 2017b) included energy as one of the key priorities and outlines key objectives including ensuring reliable supply of electricity to key social and economic development areas and promoting private sector investment in energy generation and distribution through public-private partnerships (PPPs) and independent power producers (IPPs). Regarding renewable energy, the MGDS advocates promoting the production and use of affordable alternative sources of energy, promoting the use of energy efficient technologies and designs and enhancing use of renewable and clean energy among underserved communities (GoM 2017b).

The energy-related goals of the MGDS are located within the context of the Malawian government's current National Energy Policy (NEP) to make the energy sector robust and efficient in support of the government's agenda of poverty reduction and sustainable economic development (GoM 2018). Learning lessons from the preceding energy policy
(2003) which was grid-centric with little mention of off-grid services, the 2018 energy policy demonstrates an aspiration to supply reliable, modern energy options for the whole population and reflects the need for policies to address the expansion of decentralized, small-scale and household-level energy. The inclusion of distributed energy as a focus in the new energy policy reflects the move towards decentralized governance and an understanding of potential roles (FF2).

The current Malawi National Energy Policy established a goal of reaching $80 \%$ electricity access by 2035 and to increase renewable energy deployment by 2030 , including the deployment of 50 "green" mini-grids (GoM 2018). Further policy commitments include promotion of SHS through incentives, subsidies and tax breaks to investors. The Malawi Renewable Energy Strategy (GoM 2017a) contains targets specific to off-grid solar, including actions to complete a study into impacts of additional fiscal incentives (such as VAT relief), adopt and enforce international standards for solar products, review import licence applications and ensure all importers of solar PV equipment are licenced.

Malawi's Decentralisation Policy 1998 devolves administrative and authority political for service delivery with several sectors (e.g. health, education and agriculture) to District Councils with responsible officers employed by district governments (GoM 2005). However, to date, energy has generally been dealt with at central government level with no district officers responsible solely for energy (IEA 2017). Although policies and initiatives indicate a willingness in government to address energy access for rural communities in a proactive and innovative manner, the realities on the ground indicate that much remains to be done. The lack of effective multi-level coordination and consultation has slowed the implementation of energy policies at a local level (FF4).

Slow progress to decentralize energy is due to a combination of factors, most notably issues of local capacity (FF7) including the technical and energy literacy required to understand energy decisions, a lack of qualified personnel to certify decentralized energy systems and the capacity to access information on energy possibilities for citizens and government awareness campaigns on matters such as energy efficiency and technology dissemination. Other challenge areas include the multi-sectoral nature of energy development in the context of weak existing governance structures for the energy sector in the Ministry for Energy (FF6), the limitations of a focus on grid extension as well as sub-standard and counterfeit energyrelated products on the market (Business Innovation Facility (BIF) 2014a).

\section{Distributed energy systems in Malawi}

In Malawi, distributed and renewable solutions are seen as essential to achieving "energy for all" by 2030 (IEA 2017). Supported by reductions in technology costs in recent years, 
Table 10 Summary of solar mini-grids in Malawi (Zalengera et al. 2019)

\begin{tabular}{lll}
\hline Location & District & Size of solar micro-/mini-grid (kW) \\
\hline Nyamvuu & Nsanje & 30 \\
Chimombo & Nsanje & 15 \\
Mwalija & Chikhwawa & 15 \\
Oleole & Chikhwawa & 15 \\
Sitolo & Mchjinji & 80 \\
\hline
\end{tabular}

new options such as Solar PV energy kiosks and micro-grids are proving feasible for meeting lower tier electricity needs (ESMAP 2014) (Roche and Blanchard 2018). In addition, innovative social business models that combine communitybased approaches with entrepreneurship are demonstrating improved sustainability (Munro et al. 2015; Katre et al. 2018) and have high potential for success in Malawi. Table 10 shows solar mini-grids in operation in Malawi. Mini-grids are allowed to charge a cost-reflective tariff, which is typically more expensive than the grid supply.

Malawi's off-grid solar PV installed capacity increased from 0.2 MW in 2007 to $10.4 \mathrm{MW}$ in 2016 (IRENA 2017) and sales of Pico Solar Products (PSP) is an active yet nascent market in Malawi, although currently less than $2.5 \%$ of households $(673,000$ people) own a PSP (Business Innovation Facility (BIF) 2014b). SHS are offered by commercial companies registered with MERA such as Powered by Nature and CEM Trading, and a variety of innovative solar delivery models have been piloted across Malawi including energy kiosks implemented by RENAMA. However, the sector is still young and learning on sustainable models for off-grid electrification in the Malawian context are yet to be well established. Rural energy projects in Malawi typically include aspects of community ownership and operation and target a public facility such as a primary school or health centre (Dauenhauer and Frame 2016). Despite providing high short-term social impact, several of these projects have fallen short of sustainability expectations, typical of the historical experience with off-grid renewable energy projects in SSA (Martinot et al. 2002; Chaurey and Kandpal 2010).

In 2012, there were an estimated 7000 off-grid PV systems installed, although the number in operation is unknown (Zalengera et al. 2014). There appear to be few case studies of sustainable rural energy business models in Malawi with adequate capacity to operate and maintain the systems and the collection of tariffs enabling cost recovery of capital investment within a reasonable timeframe, as well as operation and maintenance costs. Across Malawi, repairs and maintenance capacity and the networks of expertise required to undertake and provide education and information on these vital systemic areas of work are lacking, thus creating a barrier to diffusion of off-grid energy technologies (FF7).

Some evidence for sustainable solar business models comes from initiatives such as the Community Energy Development Programme through the Scottish governmentfunded Malawi Renewable Energy Acceleration Programme (University of Strathclyde 2015) which focuses on community support with village energy committees formed to establish
Fig. 3 Enhanced structure for Department of Energy Affairs with inclusion of district energy officers

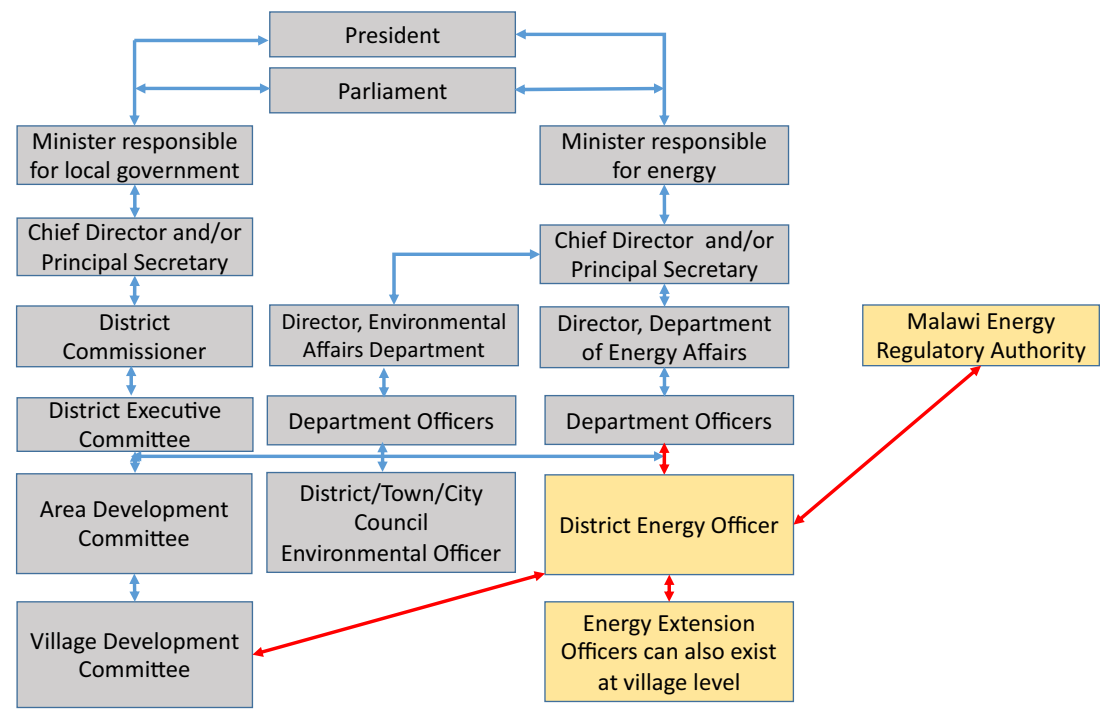


Fig. 4 Proposed activities for the DEOs (Buckland, 2017)

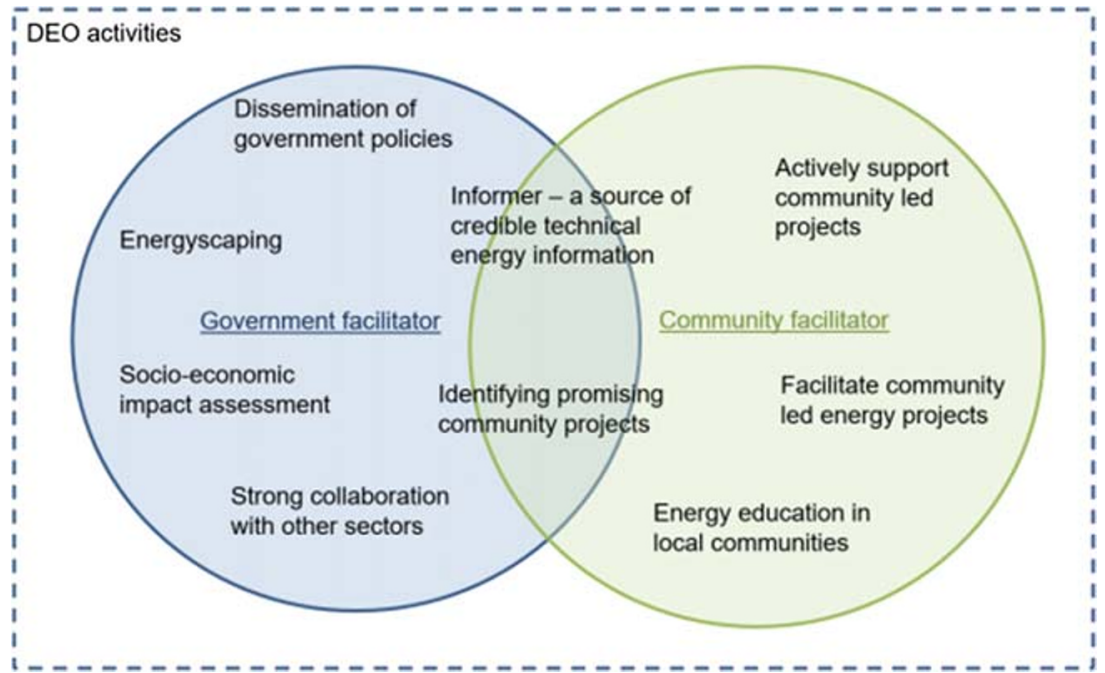

ownership for the project and Revenue Generating Activities (RGA) to pay for operation and maintenance (FF7). Each project operates under a community-based organization and the community ownership element was found to be key for sustainability. In these projects, SHS units were rented from teachers at schools and cash sales for solar lanterns formed part of the overall financial scheme. Plans to diversify include the provision of power at schools, barbershops, mobile charging and other services. Success of the project hinged upon coordination of a multitude of different organizations to ensure project sustainability (FF6).

\section{A defining role for district energy officers in Malawi?}

Malawi's National Energy Policy (MNEP) 2018 outlines that, by 2023, a district energy officer (DEO) programme to support energy sector decentralization is expected in all Malawi's districts (GoM 2018). Indeed, prior to the new energy policy, the Department of Energy Affairs was the only government department in Malawi that did not have an officer at district level. The MNEP states that the Ministry responsible for Local Government and Rural Development will be involved in identifying sites for rural electrification and the promotion of alternative energy sources in districts and supporting the DEOs.

Since 2017, the role of a DEO has been piloted by social enterprise Community Energy Malawi (CEM) in Dedza and Balaka districts with support from the University of Strathclyde, UK. CEM are feeding the results back to the GoM to inform the rollout of their DEO programme. Early negotiations were undertaken by CEM with the Government of Malawi to map a proposed role of DEOs and how it might relate to local and national structures (see Fig. 3) (FF4, 6, 7). The DEO is envisaged as being an interlocutor between community level structures such as Village Development Committees and national level authorities including the Malawi Energy Regulatory Authority
(MERA). Thus, the DEO can identify energy regulatory matters that need to be reported to MERA from district level and beyond. Simultaneously, MERA can utilize the DEO to disseminate energy regulation matters at the district level and beyond. The position of DEO also permits further decentralization of energy roles in the form of Energy Extension officers.

As part of this process, a paper was presented to the GoM (Buckland et al. 2017), outlining recommendations for the decentralization process and activities for the DEO. The activities for such a decentralized role in Malawi were categorized into three main areas and represented in Fig. 4.

1. Information exchange: "Energyscaping" the district, disseminating government policies, collaborating closely with related sectors, sourcing credible technical energy information, representing energy education in local communities

2. Facilitating energy projects: Identifying and facilitating feasible community led projects, actively supporting the implementation of sustainable community projects

3. Review: Social and economic impact assessments to calculate value for money from supporting off-grid energy and electricity developments alongside the existing grid extension framework.

Table 11 elicits the experiences of the two pilot DEOs and how these reflect the seven Framework Factors outlined in the "Factors for successful decentralized energy governance and delivery of distributed energy services in sub-Saharan Africa" section. The remit for DEOs included the following: working with the existing district structure and extension workers to advise on energy issues; providing targeted district training for high impact energy information dissemination; recording challenges faced by the communities on energy issues; and 
Table 11 Experiences of the district energy officer programme in Malawi (left hand side drawn from Eales 2019)

\begin{tabular}{|c|c|}
\hline Experience of DEO programme & $\begin{array}{l}\text { Framework } \\
\text { factor }\end{array}$ \\
\hline $\begin{array}{l}\text { Evidence that "energy awareness" of community members and decision-makers at the district } \\
\text { level has significantly increased when compared to the pre-DEO era. }\end{array}$ & FF7 \\
\hline $\begin{array}{l}\text { Increase in knowledge has unveiled a proliferation of sub-standard energy products in local } \\
\text { markets, leading to calls for more regulations and standards for energy product quality } \\
\text { control. }\end{array}$ & FF6 \\
\hline $\begin{array}{l}\text { Comprehensive "energyscaping" has revealed surprising ability to pay for energy in some } \\
\text { demographics. For example, where diesel generators are being used at a massive cost to the } \\
\text { consumer, the barrier to adoption is confusion about how to proceed with renewable energy } \\
\text { projects rather than affordability. }\end{array}$ & FF4 \\
\hline $\begin{array}{l}\text { The development of social and economic impact measurement tools for quantifying social } \\
\text { return on investment is essential to justify energy interventions against spend and allows for } \\
\text { off-grid projects to be assessed directly against other forms of developments, such as } \\
\text { national grid extension }\end{array}$ & FF3 \\
\hline $\begin{array}{l}\text { The use of mobile data collection for virtual energyscaping is a highly effective way to capture } \\
\text { and "heat map" district energy activity, targeting information dissemination to local and } \\
\text { national government decision-makers and allowing tracking of SDG7 progress. }\end{array}$ & FF4 \\
\hline $\begin{array}{l}\text { Risks to mitigate for sustainable roll out include securing financial and human resources, } \\
\text { clarifying roles between district and central government }\end{array}$ & FF2 \\
\hline
\end{tabular}

identifying, supporting and developing promising community energy projects.

The experiences documented in Table 11 as well as the role description above highlight that the DEOs are pivotal in implementing many of the framework factors. The social impact measurement allows for central government to make better informed decisions on resource allocation (FF3). DEOs have better understanding of local solar PV services and accordingly have potential to raise awareness and could be trained in product knowledge to advise on the quality of products to help communities make decisions on economic uses of distributed, solar-generated electricity (FF7). Being in contact with organizations involved in energy at a district level including NGOs, private sector and research institutions, they facilitate actor networks (FF6) as well as coordinate stakeholder interactions (FF5). By sharing information from a grassroots level on energy issues, they assist with central government planning and policy decisions, facilitating effective coordination between levels of governance (FF4) and the experience on the ground helps to understand potential roles (FF2) and inform decision-making and promote autonomy at a district level (FF1). For the DEO to function well, capacity building and accountability at the local level were required and a budget required to support interventions (FF1, 3, 7).

Although the energy sector lags behind the rest of Malawian governance as regards decentralization, progress is being made through careful strategizing evidenced by the newly established DEO programme. These moves will act as a supporting nexus for all sectors of government and will have ripple effects across the breadth of governance. When moving away from centralized supply, the Malawian case study points out that for poor, dispersed rural communities, electricity supply is not enough. Projects must be designed to be run as businesses by the communities themselves and enhanced livelihoods components to increase community income must be built in, rather than assumed to evolve from the provision of electricity. The case study demonstrates that the socioeconomic impact and sustainability of the distributed energy systems is linked to the presence and quality of dedicated local and national governance structures and actors and their interrelationships.

\section{Discussion}

Decentralized energy governance in Kenya strongly suggests that the unwillingness of the national government to cede effective power to devolved units presents a significant barrier to deployment of solar PV services and their ability to deliver sustainable long-terms benefits for communities (FF1). This has implications for states such as Malawi in respect of the current centralized situation. However,in Malawi, the relatively less powerful and developed grid utility and the more fragmented party-political environment are not directly comparable to energy structures and politics in Kenya. Both states have unbundled the functions of their state energy suppliers, KPLC in Kenya and ESCOM in Malawi, but in different ways and over different periods of time. In neither case has this resulted in central government relinquishing power. Instead, it has led to "delegation" (FF1) via the creation of additional national government institutions to take on the separated roles (KETRACO for transmission in Kenya; EGENCO for generation in Malawi). The experience in both Kenya and Malawi highlight the different roles that local authorities can play in governing distributed energy (FF2). 
Both states see energy as key for socio-economic development and are keen to promote public private partnerships and the use of independent power producers, but the Kenyan decentralization experience has only seen private investment channelled into government-controlled grid electricity. This implies that Malawi will need a clear policy framework (so far lacking in Kenya) for the timeline for the rollout of the grid and a clear understanding of how off-grid deployments are to be integrated once or if the grid arrives (FF5).

The clarity of signals from legislation are also critical if decentralized governance in countries such as Malawi is to effectively operationalize solar PV policy. The 2019 Energy Act has only partly devolved energy, leaving the grid predominantly in the hands of the national government. This has contributed to a marked grid extension and prioritization of private sector models by national and transnational actors over community led PV solar schemes (Brown et al. 2015). A dependence on donors (FF5) favouring large-scale electricity generation projects has also significantly shaped energy policy (Newell and Phillips 2016).

Further legislative ambivalence can be seen in the lengthy impasse over the 2019 Kenya Energy Act, which has left county governments in limbo regarding the roles they should adopt. The previous GoK 2006 was the key source of guidance for the first 6 years following the 2013 implementation of devolution despite not containing provision for county governments. The Kenyan experience indicates a clear need for national and county roles to be more clearly defined to avoid overlapping roles (FF4), most notably over land rights. The DEO role in Malawi appears an important step towards avoiding this uncertainty being repeated. Indeed, an interesting paradox is at play between the two countries in that Malawi is planning to introduce DEOs whose roles are being pre-defined, while Kenya's constitution devolved energy roles prior to defining them, contributing to many counties not assigning a person to undertake these roles. The Malawian approach clearly seems preferable although not a guaranteed marker of success given the frequent gap between the on-theground realities of decentralization reforms in SSA and their legislative blueprints (Erk 2014).

Underpinning the analysis above is the issue of capacity and capacity building (FF7). Local capacity building in both countries needs to be prioritized for carrying out the roles prescribed by legislation. In Kenya, county-level administrations often lack personnel, capacity and resources to develop energy plans and do not understand what investors want and what repercussions there might be (Brown et al. 2015). The effects of these shortcomings are clearly seen in the lack of off-grid PV service initiatives by county governments who primarily see energy as grid-based electricity and a national government responsibility.

Thus, local energy governance capacity must be built and encouraged from the onset in decentralization initiatives. This is particularly vital for Malawi if significant cross sectoral socio-economic impacts are to be realized. There is a need for local level understanding of how decentralized energy is critically integrated with other sectors to avoid it being neglected. Therefore, discussion and learning between the various stakeholders undertaking decentralized energy activities, along with platforms facilitating the sharing of information among stakeholders, is critical if decentralized energy governance opportunities are to be realized (Johnson et al. 2016; Brown et al. 2015).

\section{Conclusions}

The analysis above uses two specific country contexts to explore the relationship between distributed decentralized solar PV services, political decentralization and local governance. The paper points out that decentralization is not a predetermined process or set of actions, but rather a set of potentials and possibilities dependant on the seven factors identified in the analytical framework. The inherently "decentralizable" quality of solar PV technologies can act at multiple scales that dovetail into multiple energy possibilities in a way that centralized provision is unable to. The widespread deployment of solar PV can also alleviate local, regional and national dependency on expensive fossil fuels. All forms of distributed energy, but particularly solar PV in SSA, exploit the idea of multiple scalar possibilities for energy supply.

Decentralization by itself is no silver bullet; there are no guarantees implicit in decentralization of political governance and the literature and evidence give many reasons for concern. Decentralization in Kenya has been under way for some time, while symbolic moves in Malawi have been under way for even longer. However, the results are mixed: decentralization in Malawi's more fragmented party-political system may be more effective than in the political environment dominated by two coalitions in Kenya. On the other hand, Kenya's relative wealth and experience with solar PV give it a substantial advantage where decentralization of energy is concerned. Decentralization must be tailored to the historical, path-dependent development of an individual country. The effectiveness of devolved governance depends on the dynamics of complex networks of power, just as it does for the effectiveness of central governance.

Moreover, as an East African economic powerhouse, Kenya's position in intensifying globalization makes it both far more dependent on and able to use international capital and technology flows. Therefore, local energy governance in Kenya is not just local, it relates to localized access to and relations with transnational capital and global institutions (Newell and Phillips 2016). Malawi on the other hand is more detached from transnational networks and the introduction of widespread usage of solar PV there has just begun; it starts from a very different place than Kenya, geospatially, socio-culturally and technologically. 
Further research on the evolving situation in Kenya and Malawi, as well as beyond the experiences of these two countries, would be useful in building on the analytical framework developed in this paper. What the analysis here does is to raise questions about scale and institutional structure in relation to themes of governance; does the decentralization of energy issues to the local level provide opportunities for the remaking of energy landscapes, or does it just reinforce existing directions? Currently this remains unclear, but there are powerful political and commercial actors in Kenya against whose interest decentralization may be seen to act. It may also be that in Malawi, where similar systems exist but where centralized control is not as well established, decentralization of state functions has a better chance to evolve.

Acknowledgements This work was supported by a grant from the EPSRC/DFID/DECC Understanding Sustainable Energy Solutions programme under Grant EP/L002469/1. It has also been supported via funding from the EPSRC under Loughborough University's Accelerated Impact fund, the University of Nottingham's ESRC Impact Acceleration Account, and by the Scottish Government's support for the DEO blueprinting process in Malawi. The views expressed in this paper are solely the responsibility of the authors and do not necessarily reflect the views of the institutions funding the work.

Open Access This article is licensed under a Creative Commons Attribution 4.0 International License, which permits use, sharing, adaptation, distribution and reproduction in any medium or format, as long as you give appropriate credit to the original author(s) and the source, provide a link to the Creative Commons licence, and indicate if changes were made. The images or other third party material in this article are included in the article's Creative Commons licence, unless indicated otherwise in a credit line to the material. If material is not included in the article's Creative Commons licence and your intended use is not permitted by statutory regulation or exceeds the permitted use, you will need to obtain permission directly from the copyright holder. To view a copy of this licence, visit http://creativecommons.org/licenses/by/4.0/.

\section{References}

Africa Progress Panel (2015). Africa Progress Report 2015

Alupo, G.A. (2018). Kenya National Electrification Strategy: key highlights 2018. World Bank

Anyanzwa, J. (2018). Kenya's cooking gas project for the poor burnt up by graft. The East African [Online] 21 October. Available from: https://www.theeastafrican.co.ke/news/ea/Kenya-cooking-gasproject-for-the-poor-burnt-up-by-graft-/4552908-4815272cpq40bz/index.html. [Accessed: 29 Apr 2019]

Asthana AN (2003) Decentralisation and supply efficiency: the case of rural water supply in Central India. J Dev Stud 39(4):148-159

Bahingana, V. and Wa Gathui, T. (2014) "Renewable Energy and Decentralisation (READ): Rwanda Stakeholders Workshop, Kigali” [Online] Available from: http://thereadproject.co.uk/? portfolio-view=wp7-rwanda-stakeholders-workshop-report-kigali. [Accessed 3 Sept 2019]

Batchelor, S. and Smith, J. (2014a) "Beyond literacy and knowledge: energy proficiency for decentralised governance," Renewable Energy and Decentraization (READ) Working Paper 3, Project EP/ L002469/1, 2013-2015. [Online] Available from: http://
thereadproject.co.uk/wp-content/uploads/2014/04/EnergyProficiency-for-Decentralised-Governance_Working-Paper-3v29072014.pdf. [Accessed 5 Sept 2017]

Batchelor, S. and Smith, J. (2014b) "Renewable Energy and Decentralisation (READ): working paper 5; tools for improving decentralised governance of energy". [Online] Available from: http://thereadproject.co.uk/wp-content/uploads/2014/04/Tools-forImproving-Decentralised-Governance-of-Energy-Working-Paper5-v29072014.pdf. [Accessed 3 Sept 2019]

Batchelor S, Brown E, Leary J, Scott N, Alsop A, Leach M (2018) Solar electric cooking in Africa: where will the transition happen first? Energy Res Soc Sci 40:257-272

Batchelor S, Brown E, Scott N, Leary J (2019) Two birds, one stonereframing cooking energy policies in Africa and Asia. Energies 12(9):1-18

Beard V, Miraftab F, Silver C (2008) Planning and decentralisation: contested spaces for public action in the Global South. Routledge, New York

Bennett RJ (1990) Decentralization, local governments and markets: towards a post-welfare agenda. Clarendon Press, Oxford

Berkes F (2010) Devolution of environment and resources governance: trends and future. Environ Conserv 37(04):489-500

Bigsten A, Moene KO (1996) Growth and rent dissipation: the case of Kenya. J Afr Econ 5(2):177-198

Blanchard, R., Brown, E., Clements, A., Cloke, J. \& Mohr, A. (2017). Theory and praxis: co-design complexities of community energy projects in Kenya. [Online]. Available from: https://www.elsevier. com/events/conferences/international-conference-on-energyresearch-and-social-science. [Accessed: $24 \mathrm{Feb} 2018$ ]

Brown, E., Cloke, J. \& Harrison, J. (2015). Governance, decentralisation and energy: a critical review of the key issues. Working Paper 1, Project EP/L002469/1, April 2015

Brown E, Leary J, Davies G, Batchelor S, Scott N (2017) eCook: what behavioural challenges await this potentially transformative concept? Sustain Energy Technol Assess

Buckland H, Eales A, Brown E, Cloke J, Blanchard R, Yona L, Zalengera C, Batchelor S, Sieff R, Nyirenda E, Bayani E (2017) Malawi district energy officer blueprint: recommendations paper. The University of Strathclyde, Glasgow

Business Innovation Facility (BIF) (2014a) b. A survey of the pico solar product grey market in Malawi, October 2014, Blantyre, Malawi, Business Innovation Facility [Online]. Available from: https://www. bifprogramme.org/sites/default/files/attachments/pico_solar_product grey market research malawi.pdf [Accessed 23 Aug 2019]

Business Innovation Facility (BIF) (2014b) "BIF2 Malawi: pico solar products (PSP) market analysis and strategy," Business Innovation Facility, 2014

Byrne, R., Ockwell , D. G., Urama, K., Ozor, N., Kirumba, E., Ely, A., Becker, S. \& Gollwitzer, L. 2014. Sustainable energy for whom? Governing pro-poor, low carbon pathways to development: lessons from solar PV in Kenya, STEPS Working Paper 61. Available from http://steps-centre.org/wp-content/uploads/Energy-Access-online. pdf Brighton: STEPS Centre

Cabral, L. (2011). Decentralisation in Africa: scope, motivations and impact on service delivery and poverty [Online]. Future Agricultures Consortium 20 (March). pp. 1-14

Chaurey A, Kandpal TC (2010) Assessment and evaluation of PV based decentralised rural electrification: an overview. Renew Sust Energ Rev 14(8):2266-2278

Cheeseman N, Lynch G, Willis J (2016) Decentralisation in Kenya: the governance of governors. J Mod Afr Stud 54(1):p1-p35

CIO (2019). Government spends Sh27billion in Digital Literacy Programme. Available from: https://www.cio.co.ke/government-spends-sh27billionin-digital-literacy-programme/. [Accessed 27/07/2019]

Conyers D (2007) Decentralisation and service delivery: lessons from SSA. IDS Bull 38(1):18-32 
Cowell R (2017) Decentralising energy governance? Wales, devolution and the politics of energy infrastructure decision-making. Environ Plan C 35(7):1242-1263

Crook RC (2003) Decentralisation and poverty reduction in Africa: the politics of local-central relations. Public Adm Dev 23(1):77-88

D'Arcy M, Cornell A (2016) Devolution and corruption in Kenya: everyone's turn to eat? Afr Aff 115(459):246-273

Dauenhauer, P. \& Frame, D. (2016) Sustainability analysis off-grid community solar PV projects in Malawi. Seattle, IEEE Global Humanitarian Technology Conference, pp. 113-120

Day, T., Kurdziel, M.-J. \& Barasa, M. (2019). The role of renewable energy mini-grids in Kenya's electricity sector

Donahue JD (1997) Disunited states. HarperCollins Publishers Inc., New York

Eales (2019) Local energy governance for achieving SDG 7-district energy officers in Malawi, Presented at UKERC Annual Conference 2019: Local Energy Systems in National and International Contexts, Oxford April 2019

Erk J (2014) Federalism and decentralisation in SSA: five patterns of evolution. Regional Federal Stud 24(5):535-552

ESI-Africa (2016) "Kenya: electricity access stats at 56\%" [Online] Available from https://www.esi-africa.com/news/kenya-electricityaccess-stats-at-56/ [Accessed 16th August 2016]

ESMAP (2014). A new multi-tier approach to measuring energy access. [Online]. Available from: https://openknowledge.worldbank.org/ b i ts t r e m/hand le/10986/24368/ Beyond0connect0d000technical0report.pdf? sequence $=$ 1\&isAllowed=y [Accessed 4 Sept 2019]

ESMAP (2016) Upscaling mini grids for least cost and timely access to electricity services [online] Available from: http://www.esmap.org/ sites/esmap.org/files/DocumentLibrary/9515ESMAP_Mini\% 20Grids\%20Progam\%20Booklet Web.pdf [Accessed 4 Aug 2017]

ESMAP (2017). Mini grids in Kenya: a case study of a market at a turning point. [Online]. Available from: http://documents.worldbank.org/ curated/en / 792001512392701402 / pdf/ES M cKenyaMiniGridsCaseStudyConfEd-PUBLIC.pdf

European Union (EU) (2019). Approved grant operations [Online] 2019. Available from: http://www.eu-africa-infrastructure-tf.net/activities/ index.htm. [Accessed: 29 Apr 2019]

Express Communications Limited (2015). The new-look Kenya guide, 2nd. Nairobi, Kenya. Available at http://newlookkenya.com/flip/ index.html [Accessed: 3 Mar 2017]

Faguet J (2014) Decentralisation and governance. World Dev 53:2-13

GIZ (2018). Promotion of solar-hybrid mini-grids [Online] 2018. Available from: https://www.giz.de/en/worldwide/25332.html. [Accessed: 27 Mar 2018]

GMG (2018). GMG Facility - Home. [Online] Green Mini-Grid Facility. Available from: https://www.gmgfacilitykenya.org/index.php. [Accessed 19 Feb 2019]

GoK (2006) Energy Act 2006. Government of Kenya, Nairobi

GoK (2010) The Constitution of Kenya, Government of Kenya

GoK (2019) Energy Act 2019. Government of Kenya, Nairobi

Goldthau A (2014) Rethinking the governance of energy infrastructure: scale, decentralisation and polycentrism. Energy Res Soc Sci 1:134-140

GoM (2005) Ministry of Local Government and Rural Development: a strategy for capacity development for decentralisation in Malawi. [Online] Government of Malawi. Available at https://www.jica.go. jp/cdstudy/library/pdf/C20071127_01.pdf. [Accessed 2 Feb 2017]

GoM (2015) Minister of Natural Resources and Mining, 2015. [Online] Government of Malawi. Available at https://www.facebook.com/ malawigovernment/posts/431737397012760 [Accessed 2 Feb 2017]

GoM (2017a) Malawi Renewable Energy Strategy. [Online] Government of Malawi. https://wwwmeramalawimw/indexphp/resource-center/ other-regulatory-tools/download/20-other-regulatory-tools/61malawi-renewable-energy-strategy Accessed: 23rd Mar 2019

GoM (2017b) "Malawi Growth and Development Strategy (MGDS) III," [Online] Government of Malawi. Available at https://www.afidep.org/ resource-centre/downloads/policy-guidelines/malawi-growthdevelopment-strategy-mgds-iii-2017-2022/. [Accessed 23 Mar 2019]

GoM (2018) "National Energy Policy." [Online] Government of Malawi. Available at https://energy.gov.mw/index.php/resource-centre/ documents/policies-strategies?download=15:energy-policy. [Accessed 2 Feb 2017]

Gregersen, H., Contreras-Hermosilla, A., White, A. \& Phillips, L. (2004). Forest governance in Federal Systems: an overview of experiences and implications for decentralisation work in Progress Interlaken Workshop on Decentralisation in Forestry. [Online]. Interlaken. Available from: www.cifor.cgiar.org

Griffin L (2012) Where is power in governance? Why geography matters in the theory of governance. Political Stud Rev 10(2):208-220

IEA (2014) Africa energy outlook: a focus on energy prospects in SSA, World Energy Outlook Special Report. International Energy Agency, Paris

IEA (2017) IEA, "IEA —Malawi," 2017. [Online]. Available from: http:// www.iea.org/policiesandmeasures/pams/malawi/name-149519-en. php? s=dH1wZT1 yZSZzdGF0dXM9T2s, \&return= PG5hdiBpZD0iYnJ1YWRjenVtYiI-PGEgaHJ1Zj0iLyISW50ZXJuYXRpb25hbCBFbmVyZ3kgQWdlbmN5Jnp3bmo 7PC9hPjxzcGFuPiAmZ3Q7IDwvc3Bhbj48YSBocmVmPSIvc ?G9saWNpZXNhbmRtZWF. [Accessed: 21 Aug 2017]

IEA (2019) Africa Energy Outlook 2019. International Energy Agency, Paris IRENA (2017) IRENA, Renewable Energy Statistics 2017

IRENA (2019). IRENA, Renewable Energy Statistics 2019

Jacobson A (2007) Connective power: solar electrification and social change in Kenya. 35(1):144-162

Johnson, O., Nyambane, A., Cyoy, E. \& Oito, L.G. (2016). County energy planning in Kenya: local participation and local solutions in Migori County. [Online]. Available from: https://www.sei-international.org/ mediamanager/documents/Publications/SEI-WP-2016-01-Kenyacounty-energy-planning.pdf. [Accessed: 2 Jun 2016]

KAM/CEEC. (2017). At the forefront of green growth sustainability. Kenya Association of Manufacturers \& Centre for Energy Efficiency and Conservation, Nairobi

Kamau, M. (2019). Why your power bills remain high despite cheaper generation. The Standard Digital [Online] 14 May. Available from: https://www.standardmedia.co.ke/article/2001325363/transmissionlosses-aging-power-lines-inflate-your-electricity-charges

Kangu JM (2015) Constitutional law of Kenya on devolution. Strathmore University Press, Nairobi

Katre A, Tozzi A, Bhattacharya S (2018) Sustainability of communityowned mini-grids: evidence from India. Energy Sustain Soc 9(2)

Kenya Power (2017) Kenya Off-Grid Solar Access Project (KOSAP). [Online]. 2017. Available from: http://www.kplc.co.ke/content/ item/1943. [Accessed: 6 August 2017]

KETRACO (2017) "Vision 2030" [Online]. Available: http://www. ketraco.co.ke/about/vision2030.html. [Accessed: 4th Aug 2017]

Kipsang, W. (2018). Keter launches second phase of Sh15bn Last Mile project. Daily Nation [Online] 27 April. Available from: https:// www.nation.co.ke/news/Second-phase-of-Sh15bn-last-mileproject-launched/1056-4533210-mphf9jz/index.html. [Accessed: 29 Apr 2019]

KPLC (2018) Kenya leads East Africa peers in access to electricity, Kenya Power and Light Company. [Online]. Available: https:// www.kplc.co.ke/content/item/2485/kenya-leads-east-africa-peersin-access-to-electricity. Accessed 1 May 2019

Lee K, Brewer E, Christiano C, Meyo F, Miguel E, Podolsky M, Rosa J, Wolfram C (2016) Electrification for "under grid" households in rural Kenya. Dev Eng 1:26-35

Levin T, Thomas VM (2016) Can developing countries leapfrog the centralized electrification paradigm? Energy Sustain Dev 31:97-107

Lewin K (1946) Action research and minority problems. J Soc Issues 2(4):46 
Martinot E, Chaurey A, Lew D, Moreira JR, Wamukonya N (2002) Renewable energy markets in developing countries. Annu Rev Energy Environ 27:309-348

Mohmand SK, Loureiro M (2017) Introduction: interrogating decentralisation in Africa. IDS Bulletin [Online] 48(2)

Munro P et al (2015) Social enterprise development and renewable energy dissemination in Africa: the experience of the community charging station model in Sierra Leone. Prog Dev Stud 16:24-38

Musau, N. (2018). How two cabinet secretaries control electric poles tenders. The Standard [Online] 28 July. Available from: https:// www.standardmedia.co.ke/article/2001289731/revealed-the-twocabinet-secretaries-who-control-electric-poles-tenders. [Accessed: 1 May 2019]

National Statistics Office, Government of Malawi (2019) 2018 Malawi Population and Housing census Available from: http:// populationmalawi.org/wp1/wp-content/uploads/2019/10/2018Malawi-Population-and-Housing-Census-Main-Report-1.pdf. Accessed 17 Mar 2019

Ndii, D. (2019). The dam has broken. Time to call jubilee plunder what it is the elephant: E Review [Online] 18 March. Available from: https:// www.theeastafricanreview.info/op-eds/2019/03/18/the-dam-hasbroken-time-to-call-jubilee-plunder-what-it-is/. [Accessed 23 Apr 2019]

Newell, P. and Phillips, J. (2016) "Neoliberal energy transitions in the south: Kenyan experiences." Geoforum, Volume 74, August 2016, Pages 39-48

Obulutsa, G. (2019). Kenya slashes 2030 power production targets as usage still low-media. [Online]. 2019. Reuters. Available from: https://af.reuters.com/article/topNews/idAFKCN1TL0RA-OZATP. [Accessed: 10 Oct 2019]

Ockwell D, Byrne R (2016) Improving technology transfer through national systems of innovation: climate relevant innovation-system builders (CRIBs). Clim Pol 16(7):836-854

Ockwell D, Byrne R (2017) Sustainable energy for all: innovation, technology and pro-poor green transformations. Routledge, Abingdon

Ondraczek J (2013) The sun rises in the east (of Africa): a comparison of the development and status of solar energy markets in Kenya and Tanzania. Energy Policy 56:407-417

Onyeji-Nwogu, I., M. Bazilian, and T. Moss (2017) "The digital transformation and disruptive technologies: challenges and solutions for the electricity sector in African markets." [Online] CGD Policy Paper. Available: https://www.cgdev.org/publication/challenges-andsolutions-electricity-sector-african-markets [Accessed 1 Sept 2019]

Park, W. and A. Phadke (2017) "Adoption of energy-efficient televisions for expanded off-grid electricity service," In Development engineering, Volume 2, 2017, pages 107-113, ISSN 2352-7285, https://doi. org/10.1016/j.deveng.2017.07.002

Ribot JC (1999) Decentralisation, participation and accountability in Sahelian forestry: legal instruments of political-administrative control. Africa 69(1):23-65

Roche OM, Blanchard RE (2018) Design of a solar energy centre for providing lighting and income-generating activities for off-grid rural communities in Kenya. Renew Energy 118:685-694

Rodríguez-Pose A, Gill N (2003) The global trend towards devolution and its implications. Environ Plan 21(3):333-351

Romeo, L. (2012) "Decentralising for development: the developmental potential of local autonomy and the limits of politics-driven decentralisation reforms," Swedish International Centre for Local Democracy, Working Paper No. 11

Rondinelli DA, Nellis JR, Cheema GS (1983) Decentralization in developing countries. World Bank staff working paper, p 581

SE4All (2017a) "Global Tracking Framework | Tracking progress toward sustainable energy goals," 2017. [Online]. Available from: http://gtf. esmap.org/. Accessed 21 Aug 2017

SE4All (2017b) "Country Reports: Kenya" [Online]. Available from: http:/gtf.esmap.org/country/kenya. Accessed 4 Aug 2017
Sieff (2019) "Decentralised energy governance in the Global South: the case of Kenya since the implementation of devolution". PhD Thesis. Loughborough University, Loughborough

Smoke P (2015) Rethinking decentralisation: assessing challenges to a popular public sector reform. Public Adm Dev 35(2):97-112

Sovacool BK (2011) An international comparison of four polycentric approaches to climate and energy governance. Energy Policy 39(6):3832-3844

The East African Centre of Excellence for Renewable Energy and Energy Efficiency (EACREEE) (2019) EACREEE consultation meeting on energy efficiency with ministry representatives. Dar es Salaam

UN (2015). Sustainable Development Goals, United Nations. [Online]. Available from: https://www.un.org/sustainabledevelopment/ sustainable-development-goals/. [Accessed 6 May 2018]

UN (2017) “UNdata | country profile | Malawi,” United Nations [Online]. Available from: http://data.un.org/CountryProfile.aspx?crName= malawi. [Accessed 21 Aug 2017]

UN (2018) Energy sector transformation: decentralized renewable energy for universal energy access (Policy Brief No. 24), Accelerating SDG 7 Achievement: policy briefs in support of the first SDG 7 review at the UN high-level political forum 2018. Developed by Federal Ministry for Economic Cooperation and Development (BMZ), Germany, Ministry of Foreign Affairs of the Netherlands, International Renewable Energy Agency (IRENA) and World Bank

University of Strathclyde (2015) "Malawi Renewable Energy Acceleration Programme" [Online]. Available from: https://www. strath.ac.uk/engineering/electronicelectricalengineering/ o u r i n t e r n a t i o n a $1 \mathrm{prog} r$ a m m e s p r o je c t s/ malawirenewableenergyaccelerationprogramme/ [Accessed 21st Aug 2019]

Van der Plas RJ, Hankins M (1998) Solar electricity in Africa: a reality. Energy Policy 26(4):295-305

Wafula, P. (2017). Plan to split Kenya's energy docket generates heat among top ministry officials. The Standard. [Online]. 2 November. Available from: https:/www.standardmedia.co.ke/business/article/2001259099/ state-mulls-plan-to-split-energy-docket. [Accessed: 17 Apr 2018]

World Bank (2015). "Kenya's devolution" [Online]. Available from: http://www.worldbank.org/en/country/kenya/brief/kenyasdevolution. [Accessed: 7th Dec 2016]

World Bank (2018). Kenya charts path to achieving universal access to electricity. [Online]. Available from: https://www.worldbank.org/en/ news/feature/2018/12/06/kenya-charts-path-to-achieving-universalaccess-to-electricity [Accessed 22 Aug 2019]

World Bank (2019a). Kenya-World Bank Data. [Online]. Available from: https://www.google.com/search?q=world+bank+kenya+ population\&oq=world+bank+kenya+\&aqs $=$ chrome. $1.69 \mathrm{i} 57 \mathrm{j} 017$. 5661j0j4\&sourceid=chrome\&ie=UTF-8 [Accessed: 15/02/2020]

World Bank (2019b). Projects \& operations [Online] 2019. Available from: http://projects.worldbank.org/search?lang=en\&searchTerm= kenya. [Accessed: 29 Apr 2019]

WorldClim (2017). WorldClim version 2. [Online]. 2017. Available from: http://worldclim.org/version2. [Accessed: 31 Aug 2017]

Wunsch JS (2014) Decentralisation: theoretical, conceptual, and analytical issues. In: Dickovick JT, Wunsch JS (eds) Decentralisation in Africa: the paradox of state strength. Lynee Rienner, Boulder, pp 1-22

Yin RK (2009) Case study research: design and methods (fourth). Sage Publications, Inc, Thousand Oaks

Zalengera C (2019) Unpacking energy systems vulnerability and actions for resilience: lesson from Malawi. Presented at Low Carbon Energy for Development Network; 2019 May 1-3. University of Strathclyde, Glasgow

Zalengera CR, Blanchard E, Eames PC, Juma AM, Chitawo ML, Gondwe KT (2014) Overview of the Malawi energy situation and a PESTLE analysis for sustainable development of renewable energy. Renew Sust Energ Rev 38:335-347 